\title{
The Influence of Leadership Styles on Talent Management in the Banking Sector of Ghana: A Case Study of Agricultural Development Bank (ADB)
}

\author{
Bernard Bekuni Boawei Bingab ${ }^{1}$ \\ ${ }^{1}$ Department of Human Resource Management, University of Education, Winneba (UEW), Ghana \\ Correspondence: Bernard Bekuni Boawei Bingab. E-mail: bbingab@gmail.com
}

Received: January 10, 2019

Accepted: February 27, 2019

Online Published: April 30, 2019

doi:10.5539/ass.v15n5p118

URL: https://doi.org/10.5539/ass.v15n5p118

\begin{abstract}
The crisis of leadership seems to be the most pertinent problem the continent of Africa is battling with in contemporary time. Available statistical figures have consistently shown that most African countries are ranked among the lowest in global benchmarks such as life expectancy, human trafficking, control of corruption and failed state index among others. The banking sector in Africa and Ghana in particular have not been spared of this leadership crisis either. The aftermath of this is the ensuing distress the financial sector in Ghana is exposed to leading to the collapse of banks and other forms of restructuring. This paper as a result identifies the various leadership styles in Ghana's banking sector and how this leadership style attracts and retains talents in the sector. The study finds democratic leadership style as the most prevalent one commonly practiced. Managers of the various branches of ADB were seen to have taking cognizance of the concerns of the well-being and views of their employees, who as a result felt inspired in their daily routines. However, other forms of leadership style (autocratic) were deployed depending on the type of task an employee was assigned to in the organization.
\end{abstract}

Keywords: leadership style, talent management, governance, human resource management (HRM), banking

\section{Introduction}

The crisis of leadership seems to be the most pertinent problem the continent of Africa is battling with in contemporary time (Northhouse, 2013). In Ghana for instance, there are several leadership styles that are used in the banking sector which are transformational, transactional, laissez-faire, and many more. Many scholars believed that the leadership style of a company is mainly affected by the attitude of the leader and he or she plays an important role in the productiveness of the employees (Furkan et al., 2010). Africa in general is saddled with challenges whose sources are predicated on the attitude of leaders over the last four decades (see Bingab et al., 2018; Bingab et al., 2016; Forson et al., 2017; Forson et al., 2016; Forson et al., 2015). No wonder the region has more than $95 \%$ of its members being classified as third world with lower income levels. Leadership crisis as others have described the phenomenon is responsible for the region's low ranking in global benchmarks such as life expectancy, control of corruption, failed state, per capita GDP among other standards. Criss (1999) in his opinion indicates that leadership styles can be influenced by the personality trait of the leader's level of control, organizational structure and experience, an attribute the region lacks on a continuum. Therefore, governance is not a "one size fits all" matter; but rather calls for managers to adapt their approach to fit a situation or a specific group and this is why it is useful to have a thorough idea of various leadership techniques. This is against the backdrop that the more styles managers are familiar with, the more tools they will be able to use to lead effectively (Murray, 1938). In other words, the particular leadership style used by a manager will mostly be influenced by the situation or the kind of people that manager might be faced with or handling at that specific moment.

However, factors which lay the foundation for the attraction and retention of employees must be analyzed by the organization. Talent management as a concept has gained strategic importance in human resource management against the understanding that talents in individuals can make a significant difference to the current and future performance of an organization (Schullin, 2010). In the words of Lockwood (2007), having the right talent is a fundamental reason there seem to be an unprecedented change in an increasingly global marketplace, with many companies competing for talent. In recent times, many global organizations are aware of and confirm the point 
that knowledge, skills, and the abilities of talented employees are considered as important sources of competitive advantage. Nevertheless, these organizations are faced with the increasing shortage of talented people (Scullion \& Collings, 2006). Hence, strong leaders tend to make connection with talented employees in respect of the company's strategy and goals. The decision of the organization to maintain these employees is informed by the fact that management wants employees to make a positive impact (Zhang et al., 2015).

The kind of style employed by anyone in the spheres of influence would one way or the other affect the management of talents within the organization (directly and indirectly). As far as the financial sector is concerned, leadership style is crucial for both productivity and efficiency. Financial intermediaries such as banks play a mediating role between depositors and investors, with other auxiliary financial services to entrepreneurs either in the form of fund allocation or in an advisory capacity in starting new businesses (Lawson, 2012). In relation to the financial crisis currently affecting Africa, particularly Ghana, the interest of studying these relationships has become indispensably unavoidable.

In the process of studying the productivity of an organization, an avalanche of factors come to mind with the talent availability and leadership style as the most striking one. Moreover, banks over the last two decades have shifted focus to leadership as a means to providing second to none services to customers in a competitive market. In the words of Berry (1984), bank employees should be considered by managers as internal customers. According to his belief, achieving a necessary level of customer happiness in the banking industry is not possible without simultaneously concentrating on their employees. With respect to the mentioned issues, this study aims to investigate the relationship between leadership styles and talent management in the banking sector of Ghana, thus, how talent management is affected by various leadership styles.

However, although a lot of inquiries have been carried out on talent management in the African Banking Sector and worldwide (see Mensah, 2015; 2018), yet, there are absolutely dearth studies on the influence of leadership style on talent management in the Ghanaian and African Banking Sector as a whole. The author draws inspiration from the vacuum and seek to fill this void. In other words, this study is aimed at drawing the attention of policy makers to the significance of relationship between talent management and the style of leadership within the banking industry, which could ultimately affect organizational performance and productivity. When discussing leadership styles in the Ghanaian context, certain questions become indispensable. For instance, one would want to know what kind of leadership style(s) exist in the banking sector of Ghana? Which of these styles attracts talents to the sector? To what extent does this leadership style(s) affect employee retention and to spur the organization on? These and other questions are addressed in this study.

The contribution of the paper therefore is to examine and identify the predominant leadership style among the host styles that exist in the Ghanaian Banking sector. This has important implication as an understanding into the prime leadership style would allow decision makers to be able to examine the type of leadership style that attracts talents to the sector. Moreover, human resource managers would be able to link leadership style with that of employee retention as the organization progresses.

The paper is organized as follows. Section one introduces the context and explicate on the contribution the paper seek to advance informed by the questions posed in the problem statement. Section two reviews extant literature on talent management and leadership style in general and draws the empirical connections among these concepts and constructs. Research methodology is in section three where the sample technique and how data was analyzed is touched on. Section four discusses the findings of the study and concludes in section five with some recommendations.

\section{Review of Literature}

\subsection{Leadership as a Concept and Its Styles}

Leadership is all about governance which is touches on both formal and informal exercise of authority as permitted by law. It explains de facto rights and tasks of individuals engaged in any action that is found in the ambit of a particular framework operated by a firm (Eurydice, 2008). Historically, researchers have understudied the concept and have as a result brought to the fore various theories on leadership in deepening understanding on the behavioural pattern of individuals who exert some level of influence (Bass, 1990). Consequently, the research community is inundated with a number of definitions all geared toward the description of leadership. However, differences in context have given rise to differing views and opinion on the description of leadership leading to what has been described as bias (Northouse, 2010). While a section of the research community have focused on traits, values, others are interested in situations or context (Bass, 1990). In the words of Northouse (2007), leadership is explained as "a process whereby an individual influences a group of individuals to achieve a common goal". 
Leadership style on the other hand looks at a particular behavior applied by a leader to stimulate subordinates to accomplish specific organizational goals (Muindi, 2010; Hamed \& Ismi, 2013). According to Mullins (2005), leadership style gets to do "with the way in which the function of leadership is carried, the manager way in which the manager typically behaves towards members of the group". Leadership style is the relative stable pattern of behavior that exemplifies a leader (Durbin, 2010).

Leadership approach are varied and no single style is necessarily better, thus, the effectiveness of a leadership style depends on the particular or existing situation. Quite a number of leadership models have been used to describe leadership and its effectiveness. The great man theory as popularized by Carlyle (1840) is based on the idea that leaders are born with innate, unexplainable leadership skills, which cause other people to see them as heroes. It is based on the opinion that leaders are right and leadership is rooted in the authority of their righteousness.

Trait theories, often used to understand how great man are made brings to the fore explanation on the phenomenon. Trait approach to the understanding of leadership perceives leadership as the core of organization effectiveness and performance. Similar to the great man theory, is the assumption that great leaders are born with features that distinguishes them from the ordinary and thus makes them different from other people. Other researchers have concluded that possession of some traits is relevant for leadership effectiveness. This not differs from the normative idea that leaders are born and not made. We find the results of the trait studies to be increasingly inconclusive. Traits, which is a fundamental cultural value is difficult to objectify and measure. For instance, how is one able to measure traits such as integrity, loyalty and honesty? Therefore with these bottlenecks, there was the need to evolve another approach when studying leadership. After the seminar contribution of McGregor's (1960) in his classic book "The Human Side of Enterprise", attention on leadership have somewhat shifted to behavioural theories. The emphasis is on leader's behaviour as opposed to personal traits/characteristics. Yet, the relevance of behavioural theories may help managers develop particular leadership behaviors they give little guidance as to what should constitute effective leadership in different situations. Certainly, researchers of today have collectively concluded that no one leadership style is right for every manager under all circumstances. Therefore, a situational based theory or contingency-situational theories were developed to indicate the need for a particular style to be applied based on the context and situation. The Path-Goal Leadership Model and Fielder's contingency theory are classical examples.

Fiedler (1967) had theorized that there is no one size fit all approach for managers to lead and that the situation as of that time will determine the appropriate style. Thus the answer to a managerial situation is contingent on the factors that impinge on the situation. Managers were ranked or grouped on the basis of relationship oriented or task oriented. Task oriented managers tend to do better in situations that have good leader-member relationships, structured tasks and either weak or strong position power. They perform creditably well when the task is unstructured but position power is strong. Yet relationship oriented managers are thought to perform better in all other situations. Thus, a given situation might call for a manager with a different style or a manager who could take on a different style for a different situation.

Path-goal model is subservient to the theory of motivation of goal setting and expectancy. According to Oluwatoyin (2006), the essential principle of this model is that leadership behaviour should be motivating and satisfying to the extent that it increases goal attainment by subordinates and clarifies the behaviour that will lead to these goals and rewards.

The success or failure of proper organizations, nations and other social units has been largely credited to the nature of their leadership style (Oladipo et al., 2013). Leadership styles are manifold and no one style superior in any shape and form in a given situation. To greater or lesser degrees, leaders can be autocratic, democratic, transformational, transactional, and so on. The kind of leadership style exhibited by a leader may either increase motivation, commitment, attraction, retention, productivity, and so on or otherwise (Armstrong, 2016). The classification of the styles of leadership may sometimes be based on the way these leaders communicate their visions and present themselves before their followers.

Democratic leadership style is displayed where the emphasis of power is more towards the group as a whole, and where there is greater communication among the group (Mullins, 2002). The manager as a result shares the leadership tasks with members of the group where he or she takes part as a team member. This style is characterized by enthusiasm, cooperation, acceptance of more responsibility, and recognition of the value of each employee (Alhassan \& Ibrahim, 2014).

Autocratic leadership style is viewed as task-oriented (Dubrin, 1998). The manager preserves most authority for himself and undertake decision with the mind that subordinates will implement it and is not bothered about 
attitudes of the subordinates toward a decision, rather concerned about getting the task done. In some cases, like emergency situation, this style may be suitable, practical and useful.

According to scholars such as Gopal and Chowdbury (2014), the laissez-faire leadership style is a non-transactional kind of leadership style in which necessary decisions are not made, actions are delayed, leadership responsibilities ignored, and authority unused. The leader grants complete freedom and autonomy to the employees of the organization. This style is mostly used in situations where employees are matured and experienced. A study by Roy (2006) concluded that Situational Leadership can be used as a framework to furnish leaders with the guidance to coach their employees throughout the performance coaching cycle. Situational Leadership serve as a guide to the leader in setting the degree of participation for the planning and goal-setting process.

\subsection{Talent Management}

According to Hansen (2007), talent in every organizations may comprise core employees and competences including core leaders who drive the business forward (see Berger \& Berger, 2004). Talent is now a main driver of the performance of organizations. The ability of organizations to attract, employ, develop, and retain talent is determined by the success and effectiveness of the organization in the future. In principle, talent is the vehicle that helps the organization in going forward (Morton, 2005).

Talent management in itself is a broader subject and thus it becomes very necessary to expand it into its various elements of retention, development and talent acquisition. With better talent acquisition, employee engagement is enhanced thereby affecting productivity. It should be noted further that it is only a talent resourcing process that is well-defined and well-executed from start to finish yields consistent, compliant results - and is a competitive advantage in the war for talent (Ronn, 2007). However, it is acknowledged that talent development represents an important component of global talent management (Scullion \& Collings, 2011; Barlow, 2006; CIPD, 2011). Talent development focuses on the planning, selection and implementation of development strategies for the entire talent pool to ensure that the organization has both the current and future supply of talent to meet strategic objectives and that development activities are aligned with organizational talent management processes. Labour shortages as a result of an aging workforce and the growing scarcity of highly skilled workers, will clearly establish employee retention as the major talent management concern that organizations must confront in the next decade (Fegley, 2006). Hence, recruitment and retention of employees becomes a critical business issue. Organizations will not be able to maintain a competitive advantage in the marketplace if they fail to focus on their human capital, the most valuable asset to their organization. So the recent study will focus on the talent management processes, which are: acquisition, development and retention.

\subsection{Empirical Studies}

Were (2015) whilst investigating the effects of transformational leadership styles on talent management in the micro, small and medium sized enterprises in Migori County, found that there is a positive and a significant relationship $(\mathrm{r}=0.447)$ between leadership style and talent management. Chemobo, Chege, Musiega and Mute (2014) investigated the effects of transformational leadership style on teacher efficiency in public secondary schools in Kakamega Central Sub County. The study found out that transformational leadership style had significant effect on teacher performance. Makworo and Abok (2014) investigated factors affecting talent management in state corporations. The study indicated that recruitment and selection, development and compensation have positive and statistically significant effect integrating talent management. Wakabu (2015) whilst investigating leadership styles and their impact on staff retention in Uganda, the study revealed the presence of an inverse relationship between various leadership styles and employee's intention to leave.

The intensive review of literature reveals that there is not adequate researches focused on the subject of talent management and leadership style. Though less in number but there are also studies on the impact of leadership style on staff retention as well. However, it is very rare to come across studies which have been conducted on the impact of leadership style on talent management in the public banking industry. Therefore, the intention of the researcher is to find out how far leadership styles becoming parameters can impact the management of talents in a selected sector like this.

\section{Research Methodology}

The paper reviewed studies on leadership and talent management. In addition, questionnaires were administered in a field survey consisting of 200 participants drawn from a sampling frame of 800. Questionnaires were designed and administered to obtain data on three specific leadership styles (demographic, autocratic and laissez-faire) and how they affect the attraction and retention of talents in the banking sector. The participants 
were conveniently selected across specific branches of the bank. The response rate was 141 (70.5\%). The data received from the respondents were analyzed with the help of the statistical software program, SPSS_20.

\section{Analysis and Discussion}

A total of two hundred (200) questionnaires were distributed among the confirmed, full-time employees in different locations of the bank in collecting data. From the survey data, one hundred and forty-one (141) out of two hundred (200) sampled respondents filled and returned the questionnaires, contributing to $70.5 \%$ of response rate.

The results of the analyzed questionnaires suggest that the leadership style that prevails in the Agricultural Development bank is democratic. It is evident that majority of the leaders are democratic-centered. The democratic-centered style of leadership places strong emphasis on the welfare and motivation of subordinates. Leaders, with this style are more sensitive to the needs and feelings of the employee. Again, they are supportive to their subordinates, helpful to them and have concern for their well-being and also exhibited where the focus of power is more towards the group as a whole, and where there is greater interaction within the group. However, it is also evident that most leaders exhibit autocratic leadership style in some cases where the focus is only on the job to be done. A leadership style is said to be autocratic where superiors are more interested in the work to be done than in the people they work with and only motivate employees to give their best in order to increase production. The autocratic leaders, like the typical transactional leaders, are able to entice subordinates to perform and thereby achieve desired outcomes by promising those rewards and benefits for the accomplishment of tasks.

This study also aimed at determining what leadership styles influence the attraction of talents into the organization. From the analyzed data, there is a significant correlation between autocratic leadership style, democratic leadership style and attraction of talents. For example, being included in decision making gives employees the opportunity to be assigned tasks that allow them to better express their talents and skills. This in turn makes the organization an organization of choice for any talent. The results suggest that the relationship between autocratic leadership style and talents attraction is statistically significant ( $\mathrm{p}$-value of 0.000 ). Democratic leadership style and talent attraction had a correlation coefficient of 0.199 and a p-value of 0.018 therefore denoting statistical significance. Laissez-faire leadership style and talent attraction had a correlation coefficient of $-0.023, \mathrm{p}=0.782$ further pointing to a statistical insignificance. Therefore, it is evident that democratic and autocratic leadership styles have a high impact or influence on the attraction of talents into the organization, thus, the more positive the correlation coefficient between leadership styles and talent management, the stronger the impact of the leadership style on talent management.

The study also aimed at establishing the extent to which leadership styles affect retention of employees in the organization, which respondents agreed to a great extent by a mean score of 3.69, which implies that respondents' leaders included them in decision making to a great extent by a mean score of 3.89, the management of the organization provided guidance without pressure to a great extent by a mean score of 3.85 , respondents' leaders give frequent and supportive communication to a greater extent by a mean score of 4.07 , respondents work with leaders to solve differences to a great extent by a mean score of 3.92, leaders motivated employees by offering rewards and punishments to a great extent by a mean score of 3.70 .

However, it is to a lower extent that respondents feel insecure about their work by a mean score of 2.79 , respondents work without the interference of leaders to a great extent by a mean score of 3.60. therefore, it is evident that leadership styles affect employee retention to a great extent, thus, the higher the mean the greater the extent at which leadership styles affect employee retention.

\section{Conclusion and Recommendation}

In this paper, there is an attempt to identify the predominant leadership style among the avalanche of leadership traits in Ghana's banking sector and how it attracts and retains talents in the sector. The study finds democratic leadership style as the most prevalent one commonly practiced. Managers of the various branches of ADB were seen to have taking interest in the well-being and views of their employees, who as a result felt driven in their responsibility. This is possible due to the fact that anytime employees feel insecure about their work, the probability that they will leave is increased and when they are provided guidance without pressure, they hardly think about leaving the organization. However, other forms of leadership style (autocratic) were deployed depending on the type of task an employee was assigned to in the organization.

This study recommends that the leadership style to be employed should be based on certain situations since it has been proven from this study that leadership styles influence talent attraction and retention. The leader must know 
when to exhibit any leadership style since an improper choice might result in a loss of talent (turnover). Furthermore, those in the hem of affairs should be provided with training on transformational and charismatic leadership, which from research is a prerequisite for a successful manager-employee relationship. As the world is evolving, improved ways of doing things are being introduced, therefore, the organization should adopt other improved leadership styles which will help attract talents and also retain them. These two styles go beyond the prevailing leadership style (democratic) since they have the ability to inspire and motivate subordinates to attain greater results than originally planned, and also the subordinates end up gaining self-satisfaction and becoming part of the team because according to research, followers enjoy being with a Charismatic or Transformational leader, hence increase the attraction of talents.

\section{References}

Afful-Broni, A. (2004). Theory and Practice of Educational Leadership in Ghana. Accra: Yamens Press Limited.

Ahadzi et al. (2017). Effect of Leadership Behavior on Employees Performance in Electricity Company of Ghana, Winneba Municipality. University of Education, Winneba. Unpublished research project, 13-29.

Alhassan, Y., \& Ibrahim, O. (2014). Assessing the Effects of Leadership Styles on Staff Productivity in Tamale Polytechnic, Ghana. International Journal of Economics, Commerce and Management, 3.

Armstrong, M. (2016). Armstrong's Handbook of Management and Leadership for HR; Developing Effective People Skills for Better Leadership and Management. London: Kogan Page Limited.

Bingab, B. B. B., Forson, J. A., Mmbali, O. S., \& Baah-Ennumh, T. Y. (2016). The Evolution of University Governance in Ghana: Implications for Education Policy and Practice. Asian Social Science, 12(5), 147-160.

Bingab, B. B. B., Forson, J.A., Abotsi, A. K., \& Baah-Ennumh, T. Y. (2018). Strengthening University Governance in Sub-Sahara Africa: The Ghanaian Perspective. International Journal of Educational Management, 32(4).

Çetin, M., Karabay, M. E., \& Mehmet, N. E. (2012). The Effects of Leadership Styles and the Communication Competency of Bank Managers on the Employee's Job Satisfaction: The Case of Turkish Banks. Journal of Procedia - Social and Behavioral Sciences, 58, 227-235.

Chikumbi, C. (2011). An Investigation of Talent Management and Staff Retention at the Bank of Zambia. Nelson Mandela Metropolitan University Business School, Port Elizabeth. Published dissertation, 70-71.

Fiedler, F. E. (1987). Situational Theory: A theory of leadership effectiveness. New Jersey: Prentice Hall.

Forson, J. A., Baah-Ennumh, T. Y., Buracom, P., Chen, G., \& Peng Z. (2016). Causes of Corruption: Evidence from Sub-Saharan Africa. South African Journal of Economic and Management Sciences, 19(4).

Forson, J. A., Buracom, P., Baah-Ennumh, T. Y., Chen, G., \& Carsamer, E., (2015). Corruption, EU Aid Inflows and Economic Growth in Ghana: Cointegration and Causality Analysis. Contemporary Economics, 9(1), 299-318.

Forson, J. A., Buracom, P., Chen, G., \& Baah-Ennumh, T. Y. (2017). Genuine Wealth Per Capita as a Measure of Sustainability and the Negative Impact of Corruption on Sustainable Growth in Sub-Sahara Africa. South African Journal of Economics, 85(2).

Mensah, J. K. (2015). A “coalesced framework" of talent management and employee performance: For further research and practice. International Journal of Productivity and Performance Management, 64(4), 544-566. https://doi.org/10.1108/IJPPM-07-2014-0100

Mensah, J. K. (2018). Talent Management and Employee Outcomes: A Psychological Contract Fulfillment Perspective. Public Organization Review. https://doi.org/10.1007/s11115-018-0407-9

Nanjundeswaraswamy, S. T., \& Swamy, D. R. (2014). Leadership styles. Review Paper, 57-58.

Ndethiu, E. (2014). The Effects of Leadership Styles on Employee Engagement in an International Bank with substantial operations in Kenya. United States International University, Nairobi. Published dissertation, 60.

Oladipo et al. (2013). Review of leadership theories and Organizational Performances. International Business Management Journal, 50-55.

Yeboah, K. K. (2017). Collapse of UT and Capital banks-A case of a collective national failure. Article 572133. 


\section{Copyrights}

Copyright for this article is retained by the author(s), with first publication rights granted to the journal.

This is an open-access article distributed under the terms and conditions of the Creative Commons Attribution license (http://creativecommons.org/licenses/by/4.0/). 